\title{
Rhizobium cellulosilyticum sp. nov., isolated from sawdust of Populus alba
}

Correspondence

Encarna Velázquez evp@usal.es

\author{
Paula García-Fraile, ${ }^{1}$ Raúl Rivas, ${ }^{1,2}$ Anne Willems, ${ }^{2}$ Alvaro Peix, ${ }^{3}$ \\ Miet Martens, ${ }^{2}$ Eustoquio Martínez-Molina, ${ }^{1}$ Pedro F. Mateos ${ }^{1}$ \\ and Encarna Velázquez ${ }^{1}$
}

\author{
1Departamento de Microbiología y Genética, Universidad de Salamanca, Spain \\ ${ }^{2}$ Laboratorium voor Microbiologie, Vakgroep Biochemie, Fysiologie en Microbiologie, Universiteit \\ Gent, K. L. Ledeganckstraat 35, B-9000 Gent, Belgium \\ ${ }^{3}$ Instituto de Recursos Naturales y Agrobiología, IRNA-CSIC, Salamanca, Spain
}

\begin{abstract}
During a study of polysaccharide-hydrolysing bacteria present in different plant sources, two strains were isolated from pulverized decaying wood of Populus alba and classified in the genus Rhizobium on basis of their almost complete 16S rRNA gene sequences. Their closest phylogenetic relatives were Rhizobium galegae USDA $4128^{\top}$ and Rhizobium huautlense $S 02^{\top}$, with 98.2 and $98.1 \% 16 S$ rRNA gene sequence similarity, respectively. rec $A$ and atp $D$ sequence analysis showed that these species have less than 88 and $92 \%$ similarity, respectively, to the novel strains. In contrast to their closest phylogenetic relatives, the two strains showed strong cellulase activity on plates containing $\mathrm{CM}$-cellulose as a carbon source. They were also distinguishable from these species on the basis of other phenotypic characteristics. The strains were able to induce ineffective nodules on Medicago sativa and the sequence of their nodD gene was phylogenetically close to that of Ensifer meliloti 1021 (99.6\% similarity). DNA-DNA hybridization values ranged from 10 to $22 \%$ with respect to $R$. galegae USDA $4128^{\top}$ and 14 to $25 \%$ with respect to $R$. huautlense $\mathrm{S} 02^{\top}$, showing that the strains from this study belong to a novel species, for which the name Rhizobium cellulosilyticum sp. nov. is proposed. The type strain is $\mathrm{ALA}_{10 B 2}{ }^{\top}$ (= LMG $23642^{\top}=\mathrm{DSM} 18291^{\top}=$ CECT $7176^{\top}$ ).
\end{abstract}

The species of the genus Rhizobium are traditionally considered as legume endosymbionts and, although Rhizobium daejeonense was isolated from a cyanide-treatment bioreactor (Quan et al., 2005), most of them have been isolated from nodules. Decaying wood is a good source of polysaccharide-hydrolysing micro-organisms, and we have previously isolated several species, mainly actinomycetes, able to hydrolyse xylan and cellulose from similar sources (Rivas et al., 2003, 2004a, b, c, d). In this work, from pulverized decaying wood of Populus alba, we isolated two Gram-negative strains, ALA10B2 ${ }^{\mathrm{T}}$ and ALA38.2, that

Abbreviation: TP-RAPD, two-primers randomly amplified polymorphic DNA.

The GenBank/EMBL/DDBJ accession number for the 16S rRNA gene sequence of strain $\mathrm{ALA}_{10 B 2}{ }^{\top}$ is D0855376, those for the atpD sequences of strains $\mathrm{ALA}_{10 B 2}{ }^{\top}$ and ALA38.2 are AM286426 and AM286429, respectively, and those for the recA sequences of strains ALA10B2 ${ }^{\top}$ and ALA38.2 are AM286427 and AM286428, respectively.

A demonstration of cellulase activity, TP-RAPD profiles, an extended 16S rRNA gene-based neighbour-joining tree, atpD-, recA- and nodDbased neighbour-joining trees, images of nodules and plasmid profiles are available as supplementary material in IJSEM Online. actively hydrolyse CM-cellulose in vitro. The $16 \mathrm{~S}$ rRNA gene sequences of these strains allowed their classification in the genus Rhizobium, near to Rhizobium galegae and Rhizobium huautlense, two species that do not produce cellulases under the conditions used in this study. A polyphasic study of these strains, including phenotypic and molecular taxonomic approaches, showed that they belong to a novel species of the genus Rhizobium.

For isolation of strains ALA10B2 ${ }^{\mathrm{T}}$ and ALA38.2, a sample of pulverized decaying wood was collected aseptically from a cavity in the trunk of a healthy Populus alba tree in Salamanca, Spain. From this sample, $1 \mathrm{~g}$ was ground, placed in $9 \mathrm{ml}$ sterile water and stirred for $60 \mathrm{~min}$. Aqueous portions $(100 \mu \mathrm{l}$ of the mixture) were spread on CEA medium containing $0.7 \% \mathrm{CM}$-cellulose as the only carbon source, $0.3 \%$ yeast extract and $2.5 \%$ agar. Colonies were picked from these plates and inoculated on the same medium. Cellulase activity was detected after 5 days incubation at $28{ }^{\circ} \mathrm{C}$ after staining with a $1 \%$ aqueous Congo red solution. Two bacterial strains, ALA10B2 ${ }^{\mathrm{T}}$ and ALA38.2, showing strong cellulase activity, were isolated (see Supplementary Fig. S1, available in IJSEM Online). 
These strains were subjected to two-primers randomly amplified polymorphic DNA (TP-RAPD) pattern analysis, performed as described previously (Rivas et al., 2002a) using primers $879 \mathrm{~F}$ ( $5^{\prime}$-GCCTGGGGAGTACGGCCGCA-3') and 1522R ( $5^{\prime}$-AAGGAGGTGATCCANCCRCA-3'), which respectively correspond to Escherichia coli positions 879-898 and 1509-1522. The patterns obtained contain a band that corresponds to the fragment of the 16S rRNA gene amplified with these primers and several others produced by random amplification of the total DNA (Rivas et al., 2001, 2002a). According to our previous results, bacterial strains showing identical TP-RAPD patterns belong to the same species, and strains with different TP-RAPD patterns belong to different species (Rivas et al., 2001, 2002a; Zurdo-Piñeiro et al., 2004). The TP-RAPD patterns of strains ALA10B2 ${ }^{\mathrm{T}}$ and ALA38.2 (Supplementary Fig. S2, lanes 1 and 2) were the same, but were different from those of strains of R. galegae (lane 3 ) and $R$. huautlense (lane 4), suggesting that they belong to the same species, but to a different species from their closest phylogenetic relatives.

Nearly complete $16 \mathrm{~S}$ rRNA gene sequences of the strains isolated in this study were obtained according to a previously described method (Rivas et al., 2002b). The sequences of strains ALA10B2 ${ }^{\mathrm{T}}$ and ALA38.2 exhibit $100 \%$ similarity and therefore only the sequence of the strain ALA10B2 $2^{\mathrm{T}}$ is included in the phylogenetic tree. The sequence was compared with those held in GenBank using the BLASTN program (Altschul et al., 1990). 16S rRNA gene sequences were aligned using the CLUSTAL $\mathrm{X}$ software (Thompson et al., 1997) and distances were calculated according to the model of Kimura (1980) and the neighbour-joining method (Saitou \& Nei, 1987). Bootstrap analysis was based on 1000 resamplings. The MEGA2 package (Kumar et al., 2001) was used for all analyses. The resulting neighbour-joining tree is shown in Fig. 1 (a phylogenetic tree including a wider selection of reference strains is available as Supplementary Fig. S3). The results indicate that the strains from this study are phylogenetically related to members of the genus Rhizobium within the family Rhizobiaceae. According to $16 \mathrm{~S}$ rRNA gene sequence comparisons, the closest relatives of strain
$\mathrm{ALA}_{10 \mathrm{~B} 2}{ }^{\mathrm{T}}$ are $R$. galegae USDA $4128^{\mathrm{T}}$, showing $98.2 \%$ similarity, followed by $R$. huautlense $\mathrm{S}_{2} 2^{\mathrm{T}}$, showing $98.1 \%$ similarity.

We also determined partial $r e c A(550 \mathrm{bp}$ ) and atpD (492 bp) sequences for the two new isolates using methods and primers reported previously (Gaunt et al., 2001; Willems et al., 2003). Phylogenetic sequence analysis was performed with the Bionumerics software (Applied Maths), including sequences of close relatives available from EMBL. Distances were calculated and clustering was performed with the neighbour-joining algorithm as described above. Bootstrap analysis was performed using 500 replications. The two strains had the same sequence for each of these genes. $r e c A$ gene sequence analysis supports the separate phylogenetic position of the strains from this study within the genus Rhizobium, with Rhizobium mongolense USDA $1844^{\mathrm{T}}$ $(87.9 \%)$, R. galegae LMG $6214^{\mathrm{T}}(87.8 \%)$ and R. huautlense LMG $18254^{\mathrm{T}}$ and Rhizobium etli USDA $9032^{\mathrm{T}}$ (both $87.2 \%$ ) as the most closely related strains (Supplementary Fig. S4). atpD sequence analysis revealed similarly low sequence similarities between strain ALA10B2 ${ }^{\mathrm{T}}$ and several species from the genera Rhizobium and Ensifer. The most similar strains were 'Sinorhizobium morelense' LMG 21331 $(91.3 \%)$, Ensifer adhaerens STM $2072^{\mathrm{T}}$ (91.1\%), R. galegae USDA $4128^{\mathrm{T}}(90.1 \%)$ and $R$. huautlense $\mathrm{S}^{\mathrm{T}}{ }^{\mathrm{T}}(88.9 \%)$ (Supplementary Fig. S5). The low similarities found between the recA and atpD sequences of the strains from this study and those of $R$. galegae and $R$. huautlense, their closest neighbours from the $16 \mathrm{~S}$ rRNA gene sequence analysis, indicate that these strains may represent a separate Rhizobium species.

The white poplar tree from which the strains from this study were isolated was located in a soil in which indigenous plants of Medicago sativa constituted the main herbaceous legume plant. Therefore we included this plant in nodulation tests, performed as described previously (Velázquez et al., 2005), together with other plants of wide host range such as Phaseolus vulgaris or Macroptilium atropurpureum. The results obtained showed that the strains were able to nodulate Medicago sativa only, forming ineffective nodules (Supplementary Fig. S6).

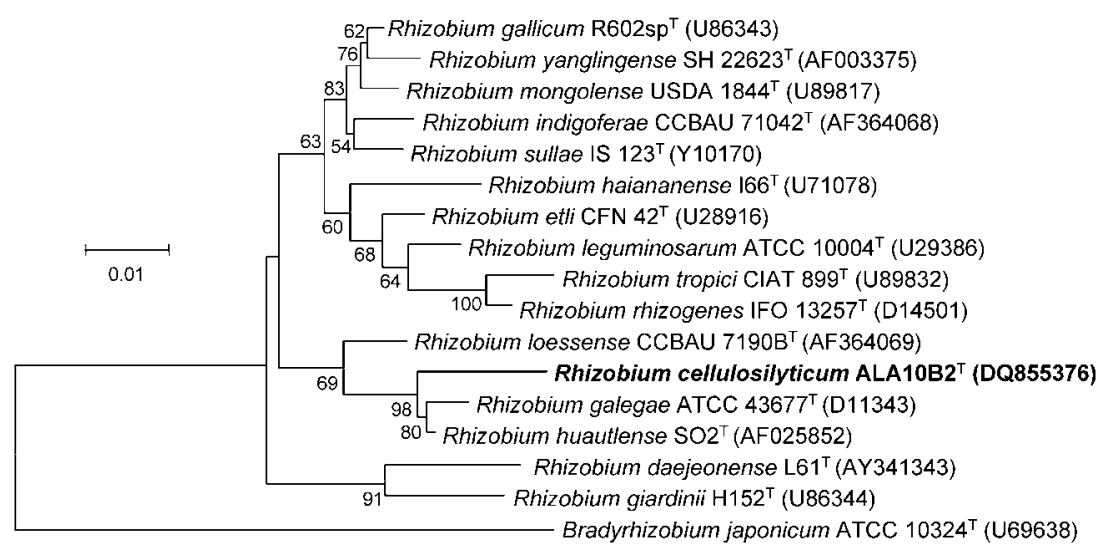

Fig. 1. Neighbour-joining tree based on nearly complete $16 \mathrm{~S}$ rRNA gene sequences of strain ALA10B2 ${ }^{\top}$ (Rhizobium cellulosilyticum sp. nov.) and related organisms of the genus Rhizobium. The significance of each branch is indicated by a bootstrap percentage calculated for 1000 subsets. Bar, 1 substitution per 100 nucleotide positions. An extended version of this tree is available as Supplementary Fig. S3 in IJSEM Online. 
The plasmid content was determined by the method of Plazinski et al. (1985), with the modifications described by Rivas et al. (2002b), using the strain Ensifer meliloti GR4 as a reference (Toro \& Olivares, 1986). The symbiotic plasmid was identified by Southern hybridization analysis. Plasmid DNA was transferred to a nylon membrane and immobilized by baking at $80^{\circ} \mathrm{C}$ for $2 \mathrm{~h}$. Oligonucleotide primers were designed to amplify fragments of the nodD and nifH genes conserved among members of the family Rhizobiaceae as described previously (Rivas et al., 2002b). PCR-amplified fragments of nodD were labelled with the DIG DNA Labelling kit (Roche Diagnostics) following the manufacturer's instructions and used as a probe. Hybridization was detected with the DIG nucleic acid detection kit (Boehringer Mannheim), using BCIP and NBT as substrates for alkaline phosphatase, according to the manufacturer's instructions. The two strains from this study showed identical plasmid profiles (represented in Supplementary Fig. S7, lane 2), with two plasmids of about 40 and $250 \mathrm{~kb}$. The plasmid of $250 \mathrm{~kb}$ was identified as the pSym after hybridization with the nodD probe (Supplementary Fig. S7, lane 4).

A partial nodD gene fragment (512 bp) from strain $\mathrm{ALA} 10 \mathrm{~B} 2^{\mathrm{T}}$ was amplified and sequenced as described previously (Rivas et al., 2002b). Comparison against sequences held in GenBank showed that the closest relative to the nodD gene from strain ALA10B2 ${ }^{\mathrm{T}}$ was that of Ensifer meliloti 1021, with $99.6 \%$ similarity (Supplementary Fig. S8). The nifH gene could not be amplified using the conditions reported by Rivas et al. (2002b). The results of nodulation tests in alfalfa showed the formation of ineffective nodules in this legume by the strains from this study (Supplementary Fig. S6).

For base composition analysis, DNA was prepared according to Chun \& Goodfellow (1995). The G $+\mathrm{C}$ content of DNA from strain ALA10B2 ${ }^{\mathrm{T}}$ was determined as $57 \mathrm{~mol} \%$ using the thermal denaturation method (Mandel \& Marmur, 1968). DNA-DNA hybridization was carried out by using the method of Ezaki et al. (1989), as described by Willems et al. (2001). The two novel strains showed 10-22\% relatedness to R. galegae USDA $4128^{\mathrm{T}}$ and $14-25 \%$ relatedness to $R$. huautlense $\mathrm{S}_{0} 2^{\mathrm{T}}$ (Supplementary Table $\mathrm{S} 1$ ). These results indicate that strains ALA10B2 ${ }^{\mathrm{T}}$ and ALA38.2 do not belong to either of these species when the recommendation of a threshold value of $70 \%$ DNA-DNA relatedness for species definition is considered (Wayne et al., 1987).

Phenotypic characterization of the strains from this study was based on growth with different carbon sources and resistance to different antibiotics, as described by Wang et al. (1998), and by using API 20NE according to the manufacturer's instructions (bioMérieux). The temperature range for growth was determined by incubating cultures in YMA medium at 4 to $40{ }^{\circ} \mathrm{C}$. The $\mathrm{pH}$ range was determined in the same medium with a final $\mathrm{pH}$ between 4.0 and 10.0. Salt tolerance was studied in YMA medium containing $0-5 \%$ $(\mathrm{w} / \mathrm{v}) \mathrm{NaCl}$. Cellulase activity was detected after 5 days incubation at $28^{\circ} \mathrm{C}$ on plates containing CEA medium as explained above. The type strains of $R$. galegae and $R$. huautlense were used as references.

Slight phenotypic differences were observed between the two strains from this study, as shown in Table 1, which also includes results for $R$. galegae and $R$. huautlense. The strains from this study differ from $R$. galegae in cellulase production, growth in the presence of $3 \% \mathrm{NaCl}$, use of L-methionine as a carbon source and resistance to erythromycin and ampicillin. They differ from $R$. huautlense in cellulase production, growth at $4{ }^{\circ} \mathrm{C}$ and $\mathrm{pH} 9$, growth in $3 \% \mathrm{NaCl}$ and resistance to kanamycin and erythromycin. Therefore, the new group can be differentiated genotypically and phenotypically from previously described species and we therefore propose to name it Rhizobium cellulosilyticum sp. nov.

\section{Description of Rhizobium cellulosilyticum sp. nov.}

Rhizobium cellulosilyticum (cel.lu.lo.si.ly'ti.cum. N.L. n. cellulosum cellulose; N.L. neut. adj. lyticum dissolving from Gr. adj. lytikos able to loose, able to dissolve; N.L. neut. adj. cellulosilyticum cellulose-dissolving).

Gram-negative rods, as for other species of the genus. Colonies are small and pearl white in YMA at $28^{\circ} \mathrm{C}$, the optimal growth temperature. The optimum $\mathrm{pH}$ is 7-7.5. Grows at $4-37^{\circ} \mathrm{C}, \mathrm{pH} 6-8$ and $0-4 \%(\mathrm{w} / \mathrm{v}) \mathrm{NaCl}$. Strains of this species actively produce cellulases on media containing

Table 1. Differential phenotypic characteristics between the strains from this study and the type strains of the phylogenetically closest species

Strains: 1, R. galegae USDA $4128^{\mathrm{T}}$ (unless indicated, data from Lindström, 1989); 2, R. huautlense $\mathrm{S}^{\mathrm{T}} 2^{\mathrm{T}}$ (unless indicated, data from Wang et al., 1998); 3, strain ALA10B2 ${ }^{\mathrm{T}}$ (R. cellulosilyticum sp. nov.); 4, strain ALA38.2 (R. cellulosilyticum sp. nov.).

\begin{tabular}{|c|c|c|c|c|}
\hline Characteristic & 1 & 2 & 3 & 4 \\
\hline \multicolumn{5}{|l|}{ Growth at/in: } \\
\hline $4{ }^{\circ} \mathrm{C}$ & $+^{*}$ & $-*$ & + & + \\
\hline $40^{\circ} \mathrm{C}$ & - & + & - & - \\
\hline $\mathrm{pH} 9$ & - & + & - & - \\
\hline $3 \% \mathrm{NaCl}$ & - & - & + & + \\
\hline Hydrolysis of CM-cellulose & - & - & $+\dagger$ & $+\dagger$ \\
\hline Urease & + & + & + & W \\
\hline \multicolumn{5}{|l|}{ Assimilation of: } \\
\hline Maltose & + & + & + & $\mathrm{W}$ \\
\hline Methionine & - & + & + & + \\
\hline \multicolumn{5}{|l|}{ Resistance to $\left(\mu \mathrm{g} \mathrm{ml}^{-1}\right)$ : } \\
\hline Ampicillin (5) & - & + & + & + \\
\hline Kanamycin (5) & - & + & - & - \\
\hline Erythromycin (5) & $+^{*}$ & + & - & - \\
\hline
\end{tabular}

${ }^{\star}$ Data from the type strains obtained in this study.

$\dagger$ After 5 days incubation, the strains formed $1 \mathrm{~cm}$ lysis 'haloes'. 
CM-cellulose as substrate. Nitrate reduction is negative. Produces $\beta$-galactosidase and hydrolyses aesculin in API 20NE. Production of urease is positive in strain ALA10B2 ${ }^{\mathrm{T}}$ but weak in strain ALA38.2. Does not produce indole, arginine dihydrolase or gelatinase in the same system. Utilizes glucose, L-arabinose, mannose, mannitol, $\mathrm{N}$ acetylglucosamine and malate as carbon sources. Maltose is used as a carbon source, but growth of strain ALA38.2 is weak. Grows on glutamate and methionine as carbon and nitrogen sources. Does not grow on gentiobiose, caprate, adipate, citrate or phenylacetate. Known strains are resistant to $5 \mu \mathrm{g}$ ampicillin $\mathrm{ml}^{-1}$ and $50 \mu \mathrm{g}$ chloramphenicol ml $\mathrm{ml}^{-1}$ and sensitive to $5 \mu \mathrm{g}$ erythromycin and kanamycin $\mathrm{ml}^{-1}$. The $\mathrm{G}+\mathrm{C}$ content of the type strain is $57 \mathrm{~mol} \%$.

The type strain ALA10B2 $^{\mathrm{T}} \quad\left(=\mathrm{LMG} \quad 23642^{\mathrm{T}}=\mathrm{DSM}\right.$ $18291^{\mathrm{T}}=$ CECT $7176^{\mathrm{T}}$ ) and reference strain ALA38.2 (=LMG 23643) were isolated from sawdust of Populus alba in Spain.

\section{Acknowledgements}

This work was supported by the Junta de Castilla y León and the Ministerio de Educación y Ciencia (Spanish Government). A. W. is grateful to the Fund for Scientific Research - Flanders for financial support. R. R. acknowledges a PhD fellowship from the MEC.

\section{References}

Altschul, S. F., Gish, W., Miller, W., Myers, E. W. \& Lipman, D. J. (1990). Basic local alignment search tool. J Mol Biol 215, 403-410.

Chun, J. \& Goodfellow, M. (1995). A phylogenetic analysis of the genus Nocardia with 16S rRNA sequences. Int J Syst Bacteriol 45, 240-245.

Ezaki, T., Hashimoto, Y. \& Yabuuchi, E. (1989). Fluorometric deoxyribonucleic acid-deoxyribonucleic acid hybridization in microdilution wells as an alternative to membrane filter hybridization in which radioisotopes are used to determine genetic relatedness among bacterial strains. Int J Syst Bacteriol 39, 224-229.

Gaunt, M. W., Turner, S. L., Rigottier-Gois, L., Lloyd-Macgilp, S. A. \& Young, J. P. W. (2001). Phylogenies of atpD and recA support the small subunit rRNA-based classification of rhizobia. Int J Syst Evol Microbiol 51, 2037-2048.

Kimura, M. (1980). A simple method for estimating evolutionary rates of base substitutions through comparative studies of nucleotide sequences. J Mol Evol 16, 111-120.

Kumar, S., Tamura, K., Jakobsen, I.-B. \& Nei, M. (2001). MEGA Molecular Evolutionary Genetics Analysis software. Tempe, AZ: Arizona State University.

Lindström, K. (1989). Rhizobium galegae, a new species of legume root nodule bacteria. Int J Syst Bacteriol 39, 365-367.

Mandel, M. \& Marmur, J. (1968). Use of ultraviolet absorbance temperature profile for determining the guanine plus cytosine content of DNA. Methods Enzymol 12B, 195-206.

Plazinski, J., Chen, Y. H. \& Rolfe, B. G. (1985). General method for the identification of plasmid species in fast-growing soil microorganisms. Appl Environ Microbiol 48, 1001-1003.

Quan, Z. X., Bae, H. S., Baek, J. H., Chen, W. F., Im, W. T. \& Lee, S. T. (2005). Rhizobium daejeonense sp. nov. isolated from a cyanide treatment bioreactor. Int J Syst Evol Microbiol 55, 2543-2549.
Rivas, R., Velázquez, E., Valverde, A., Mateos, P. F. \& MartínezMolina, E. (2001). A two primers random amplified polymorphic DNA procedure to obtain polymerase chain reaction fingerprints of bacterial species. Electrophoresis 22, 1086-1089.

Rivas, R., Velázquez, E., Palomo, J. L., Mateos, P., GarcíaBenavides, P. \& Martínez-Molina, E. (2002a). Rapid identification of Clavibacter michiganensis subspecies sepedonicus using two primers random amplified polymorphic DNA (TP-RAPD) fingerprints. Eur J Plant Pathol 108, 179-184.

Rivas, R., Velázquez, E., Willems, A., Vizcaíno, N., Subba-Rao, N. S., Mateos, P. F., Gillis, M., Dazzo, F. B. \& Martínez-Molina, E. (2002b). A new species of Devosia that forms a nitrogen-fixing root-nodule symbiosis with the aquatic legume Neptunia natans (L. f.) Druce. Appl Environ Microbiol 68, 5217-5222.

Rivas, R., Sánchez, M., Trujillo, M. E., Zurdo-Piñeiro, J. L., Mateos, P. F., Martínez-Molina, E. \& Velázquez, E. (2003). Xylanimonas cellulosilytica gen. nov., sp. nov., a xylanolytic bacterium isolated from a decayed tree (Ulmus nigra). Int J Syst Evol Microbiol 53, 99-103.

Rivas, R., Trujillo, M. E., Sánchez, M., Mateos, P. F., MartínezMolina, E. \& Velázquez, E. (2004a). Microbacterium ulmi sp. nov., a xylanolytic, phosphate-solubilizing bacterium isolated from sawdust of Ulmus nigra. Int J Syst Evol Microbiol 54, 513-517.

Rivas, R., Trujillo, M. E., Mateos, P. F., Martínez-Molina, E. \& Velázquez, E. (2004b). Cellulomonas xylanilytica sp. nov., a cellulolytic and xylanolytic bacterium isolated from a decayed elm tree. Int J Syst Evol Microbiol 54, 533-536.

Rivas, R., Trujillo, M. E., Schumann, P., Kroppenstedt, R. M., Sánchez, M., Mateos, P. F., Martínez-Molina, E. \& Velázquez, E. (2004c). Xylanibacterium ulmi gen. nov., sp. nov., a novel xylanolytic member of the family Promicromonosporaceae. Int J Syst Evol Microbiol 54, 557-561.

Rivas, R., Trujillo, M. E., Mateos, P. F., Martínez-Molina, E. \& Velázquez, E. (2004d). Agromyces ulmi sp. nov., a xylanolytic bacterium isolated from Ulmus nigra in Spain. Int J Syst Evol Microbiol 54, 1987-1990.

Saitou, N. \& Nei, M. (1987). The neighbor-joining method: a new method for reconstructing phylogenetic trees. Mol Biol Evol 4, 406-425.

Thompson, J. D., Gibson, T. J., Plewniak, F., Jeanmougin, F. \& Higgins, D. G. (1997). The CLUSTAL_X windows interface: flexible strategies for multiple sequence alignment aided by quality analysis tools. Nucleic Acids Res 25, 4876-4882.

Toro, N. \& Olivares, J. (1986). Characterization of a large plasmid of Rhizobium meliloti involved in enhancing nodulation. Mol Gen Genet 202, 331-335.

Velázquez, E., Peix, A., Zurdo-Piñeiro, J. L., Palomo, J. L., Mateos, P. F., Rivas, R., Muñoz-Adelantado, E., Toro, N., García-Benavides, P. \& Martínez-Molina, E. (2005). The coexistence of symbiosis and pathogenicity-determining genes in Rhizobium rhizogenes strains enables them to induce nodules and tumors or hairy roots in plants. Mol Plant Microbe Interact 18, 1325-1332.

Wang, E. T., van Berkum, P., Beyene, D., Sui, X. H., Dorado, O., Chen, X. H. \& Martinez-Romero, E. (1998). Rhizobium huautlense sp. nov., a symbiont of Sesbania herbacea that has a close phylogenetic relationship with Rhizobium galegae. Int J Syst Bacteriol 48, 687-699.

Wayne, L. G., Brenner, D. J., Colwell, R. R., Grimont, P. A. D., Kandler, O., Krichevsky, M. I., Moore, L. H., Moore, W. E. C., Murray, R. G. E. \& other authors (1987). Report of the ad hoc committee on reconciliation of approaches to bacterial systematics. Int J Syst Bacteriol 37, 463-464.

Willems, A., Doignon-Bourcier, F., Goris, J., Coopman, R., de Lajudie, P. \& Gillis, M. (2001). DNA-DNA hybridization study of Bradyrhizobium strains. Int J Syst Evol Microbiol 51, 1315-1322. 
Willems, A., Fernández-López, M., Muñoz-Adelantado, E., Goris, J., De Vos, P., Martínez-Romero, E., Toro, N. \& Gillis, M. (2003). Description of new Ensifer strains from nodules and proposal to transfer Ensifer adhaerens Casida 1982 to Sinorhizobium as Sinorhizobium adhaerens comb. nov. Request for an Opinion. Int J Syst Evol Microbiol 53, 1207-1217.
Zurdo-Piñeiro, J. L., Velázquez, E., Lorite, M. J., BrellesMariño, G., Schröder, E. C., Bedmar, E. J., Mateos, P. F. \& Martínez-Molina, E. (2004). Identification of fast-growing rhizobia nodulating tropical legumes from Puerto Rico as Rhizobium gallicum and Rhizobium tropici. Syst Appl Microbiol 27, 469-477. 